\title{
Effects of whey protein concentrate on shelf life of cookies using corn and sunflower oils
}

\author{
Melina Erben ${ }^{1,2}$, Hugo Diego Sánchez ${ }^{1, *}$, Carlos Alberto Osella ${ }^{1}$ \\ ${ }^{1}$ Instituto de Tecnología de Alimentos, Facultad de Ingeniería Química-Universidad Nacional del Litoral, Santa Fe, Argentina \\ ${ }^{2}$ Consejo Nacional de Investigaciones Científicas y Técnicas (CONICET), Argentina
}

\section{Email address:}

hsanchez@fiq.unl.edu.ar (H. Sánchez)

\section{To cite this article:}

Melina Erben, Hugo Diego Sánchez, Carlos Alberto Osella. Effects of Whey Protein Concentrate on Shelf Life of Cookies Using Corn and Sunflower Oils. Journal of Food and Nutrition Sciences. Vol. 2, No. 4, 2014, pp. 195-199. doi: 10.11648/j.jfns.20140204.25

\begin{abstract}
The objective of this work was to study the effect of whey protein concentrate (WPC) on shelf life of cookies using corn and sunflower oils as fat source. Wheat flour was partially replaced by WPC with levels of 5, 7.5, 10 and $15 \%$. A User Defined Design was used and the three following responses were measured: peroxide index (meqO2/kg), flavour (score from 1-10) and rancidity (detectable and non-detectable) at $0,7,14,21$ and 70 days of storage. Results show that during storage peroxide index (PI) increases in all cookies samples. However a significant decrease was found when corn oil was used instead of sunflower oil and when the level of WPC goes from $0 \%$ to $15 \%$. Regarding sensory evaluation, all cookies were evaluated as acceptable (scored flavour $\geq 6$ ) and no rancid flavour was perceived, except for two samples which were assigned with 5 and rancid flavour was considered as detectable; these samples correspond to cookies evaluated at day 70, elaborated with sunflower oil and the lowest dose of WPC. No significant differences were found in cookies flavour prepared with different oils. On the other hand and relative to the level of WPC replacement, differences were found by the panel at days 0 and 7, a reduction in assigned score when WPC dose was increased, however this difference was not significant in the subsequent assessment days. According to research results, an increase in stability was clearly obtained in cookies elaborated with corn oil and the highest concentration of WPC.
\end{abstract}

Keywords: Cookies, Whey Protein Concentrate, Corn Oil, Sunflower Oil

\section{Introduction}

One of the tools used to overcome the effects of malnutrition in children has been the development of consumer foods with improved nutritional properties by adding ingredients of high nutritional value [1]. Although they are not a main food in the diet, cookies offer features that make them attractive as a means of fortification because of their general acceptability, convenience and stability [2]. Ingredients used for making cookies are considered of low nutritive and biological values, for example soft wheat flour used is deficient in several nutrients including some vitamins, minerals and dietary fibre and contains only 7 to $10 \%$ of protein. Besides, wheat flour lacks certain essential amino acids such as lysine, tryptophan and threonine [3]. Many traditional dairy ingredients provide unprecedented opportunities for the food industry to improve existing or develop new products with unique health benefits. The value of proteins, an essential source of amino acids is well documented, but recently it has been recognized that dietary proteins exert many other functionalities in vivo by means of biologically active peptides [4]. The whey proteins are potentially nutritional and functional food ingredients for use in a wide range of food types which contributes to the supply of minerals in addition to protein [5]. Acid whey powder improves the crust colour and enhances flavour in bread, biscuits, crackers and snack foods, providing a golden surface on baking. Benefits of whey protein concentrate (WPC) in food applications include antioxidant activity due to its ability to elevate cellular glutathione levels [6].

One of the basic components of a cookie formulation is fat, present at relatively high levels. Fat acts as a lubricant and contributes to the plasticity of the cookie dough, imparts desirable eating qualities and contributes to texture and flavour of the product. The shortening used in bakery products varies in their consistency from liquid oils to high melting point plastic fats [7]. Recommendations on intake 
of this macronutrient aim at reducing consumption of saturated fatty acids. An alternative approach to reducing saturated fatty acid content is to replace some of the animal fat by healthier oils that are low in saturated fatty acid (SFA) and rich in monounsaturated fatty acids (MUFA) and polyunsaturated fatty acids (PUFA) [8]. The problem is the development of rancidity in edible oils, which are more suitable from the nutritional point of view, but have disadvantages from the point of view of stability [9]. Lipids oxidation not only produces rancid odours and flavours, also can decrease the nutritional quality and safety by the formation of secondary products in food after cooking and processing [10]. Ideally, the best oil for cooking should be a product that is not damaged by the heat applied, does not impart a bad taste or odour to the product, which has no negative effects from the nutritional point of view attributed to saturated fatty acids and hydrogenated, and its cost is reasonable [9]. Resistance of oils and fats to oxidation depends on such factors as the degree of unsaturation, the presence of antioxidants or pro-oxidants, and prior abuse [11]. Oils contain tocopherols and tocotrienols, especially $\alpha$ - and $\gamma$-tocopherols, as their main antioxidants [12].

To evaluate the performance of development products which has undergone a change in the recipe or process, shelf life studies are used. It refers to the time during which a product remains acceptable to a consumer in terms of sensory characteristics. Many factors influence the shelflife of a product, such as moisture loss, spoilage due to microorganisms, enzymatic changes and the oxidation [13]. To evaluate the shelf life different techniques are used, including sensory evaluation and chemical analysis. Sensory characteristics are most easily detected, economic and require no instrumentation [14]. The onset of rancidity, as determined by human sensory analysis, is the ultimate test for calculating induction period. "Sensory induction period" can be defined as the time required for a fat or oil to become slightly rancid as determined by a sensory panel [10]. Various tests, such as peroxide index (PI), have been developed to determine the present status of oil oxidation. PI ranges for oxidized oil have been reported to be 3-5 for low oxidation, 10-12 for moderate oxidation, and 16-18 for high oxidation [15]. Peroxides are indicators of oxidative rancidity in foods and are used as indicators of oil quality and stability [16].

The main objective of the present work was to study the effect of whey protein concentrate (WPC) on shelf life of cookies using corn and sunflower oils.

\section{Material and Methods}

\subsection{Materials}

Wheat flour provided by Molinos Sagemüller (Entre Rios-Argentina) with the following characteristics: moisture $13.6 \mathrm{~g} / 100 \mathrm{~g}$, protein $10.3 \mathrm{~g} / 100 \mathrm{~g}(\mathrm{~N} x$ 5.7), fat $1.0 \mathrm{~g} / 100 \mathrm{~g}$ and ash $0.68 \mathrm{~g} / 100 \mathrm{~g}$. WPC with moisture
$6.6 \mathrm{~g} / 100 \mathrm{~g}$, protein $30.3 \mathrm{~g} / 100 \mathrm{~g}(\mathrm{~N} \times \mathrm{6} 6.38)$ and ash 6.3 $\mathrm{g} / 100 \mathrm{~g}$, was from Milkaut (Santa Fe-Argentina). The oils used in recipe were from corn and sunflower, provided by Molinos Cañuelas (Buenos Aires-Argentina). Corn oil with $2.31 \mathrm{mg} / \mathrm{ml}$ of vitamin $\mathrm{E}$ and the sunflower oil with 0.54 $\mathrm{mg} / \mathrm{ml}$. The fatty acid composition for corn oil was $12.7 \%$ SFA, $24.2 \%$ MUFA (oleic acid) and $58.7 \%$ PUFA (linoleic acid); and for sunflower oil was $10.3 \%$ SFA, $19.5 \%$ MUFA (oleic acid) and $65.5 \%$ PUFA (linoleic acid) [17]. All ingredients used were of food quality.

\subsection{Manufacture of Cookies}

Cookies were manufactured according to the rotarymolded formula proposed by [18], with minor modifications to adapt it to a pilot plant conditions. The base formulation was: wheat flour $(200 \mathrm{~g})$, sugar $(50 \mathrm{~g})$, fat $(50 \mathrm{~g})$, salt $(1.6 \mathrm{~g})$, baking powder $(2 \mathrm{~g})$ and water $(70 \mathrm{ml})$. The wheat flour was partially replaced by WPC $(5 \%$, $7.5 \%, 10 \%$ and $15 \%$ ).

All solid ingredients were placed in an Oster mixer and mixed during $1 \mathrm{~min}$ and after that time water was added and mixed during $6 \mathrm{~min}$. After mixing, the dough was rolled on a wood table with two $2 \mathrm{~mm}$ aluminium strips at both sides and then it was allowed to rest for $1 \mathrm{~min}$. The dough was cut with a dough cutter of $4 \mathrm{~cm}$ diameter. The pieces were then placed on a cookie sheet in a rotary oven without steam at $220{ }^{\circ} \mathrm{C}$ and to achieve the appropriate colour were cooked at different times, according to the amount of WPC added. After baked, cookies were allowed to reach room temperature, removed from the baking sheet and packaged in polypropylene bags. All samples were then stored at room temperature and protected from light.

\subsection{Peroxides Measurement}

The peroxide index (PI), value in terms of meqO $\mathrm{O}_{2} / \mathrm{kg}$, was determined in oils and cookies samples by the official method of the [19]. Cookies were evaluated at 0, 7, 14, 21 and 70 days of its manufacture. All chemicals and solvents used were of analytical grade.

\subsection{Sensory Evaluation}

Sensory evaluation of cookies was conducted to determine its acceptability. Flavour was scored from 1 (least favourable) to 10 (most favourable) and the sensory descriptor for rancidity was evaluated as detectable and non-detectable [20]. Sensory quality evaluation was performed by a panel of experts in a number of three at 0,7 , 14, 21 and 70 days of storage. The panel became particularly familiar with the sensory descriptors being that had been used frequently in previous studies. Flavour and rancidity were evaluated as the most relevant sensory descriptors.

\subsection{Experimental Design}

Three responses were measured: Peroxide index, Flavour and Rancidity at $0,7,14,21$ and 70 days of its manufacture. 
Variables chosen were: Whey proteins concentrate (WPC), Sunflower oil (S) and Corn oil (C). The values of variables were established according to the User Defined Design that allows selecting all classes of candidate points using the program Design Expert 7.0.0. The range for WPC was from 0 to $15 \mathrm{~g} / 100 \mathrm{~g}$. The design matrix is shown in Table 1 .

\section{Results and Discussion}

\subsection{Peroxide Index}

Oils used in this study had PI values below the maximum allowed by the [21] (10 meqO2/Kg). These values were $3.62 \mathrm{meqO} 2 / \mathrm{kg}$ and $4.52 \mathrm{meqO} 2 / \mathrm{kg}$ for sunflower oil and corn oil respectively. Changes occurring in the PI of cookies during storage are given in Table 2.
Table 1. Design Expert-variables and levels

\begin{tabular}{ccc}
\hline Run & WPC & Oil* \\
\hline 1 & 15 & $\mathrm{C}$ \\
2 & 10 & $\mathrm{~S}$ \\
3 & 5 & $\mathrm{~S}$ \\
4 & 0 & $\mathrm{C}$ \\
5 & 5 & $\mathrm{C}$ \\
6 & 7.5 & $\mathrm{C}$ \\
7 & 10 & $\mathrm{C}$ \\
8 & 0 & $\mathrm{~S}$ \\
9 & 15 & $\mathrm{~S}$ \\
10 & 7.5 & $\mathrm{~S}$ \\
\hline
\end{tabular}

*C: Corn oil and S: Sunflower oil

Table 2. Peroxide Index of cookies during storage*

\begin{tabular}{|c|c|c|c|c|c|c|c|c|c|c|}
\hline \multirow{3}{*}{ WPC (\%) } & \multicolumn{5}{|c|}{ Corn oil } & \multicolumn{5}{|c|}{ Sunflower oil } \\
\hline & \multicolumn{5}{|c|}{ Storage (days) } & \multicolumn{5}{|c|}{ Storage (days) } \\
\hline & $\mathbf{0}$ & 7 & 14 & 21 & 70 & $\mathbf{0}$ & 7 & 14 & 21 & 70 \\
\hline 0 & 4,3 & 10,2 & 13,8 & 19,6 & 45,9 & 4,6 & 24,0 & 38,5 & 42,7 & 115,0 \\
\hline 5 & 4,2 & 8,6 & 14,3 & 14,3 & 22,8 & 4,4 & 21,3 & 38,5 & 51,6 & 115,3 \\
\hline 7,5 & 4,5 & 7,7 & 11,3 & 17,1 & 22,0 & 4,9 & 20,9 & 35,7 & 42,4 & 81,8 \\
\hline 10 & 3,8 & 9,0 & 11,2 & 9,4 & 14,5 & 4,5 & 15,6 & 28,6 & 33,3 & 92,4 \\
\hline 15 & 4,9 & 5,4 & 6,4 & 9,7 & 14,6 & 5,1 & 13,8 & 25,1 & 31,5 & 52,4 \\
\hline
\end{tabular}

*meq $\mathrm{O}_{2} / \mathrm{kg}$

As table 2 shows, PI increases during the storage in all cases however some differences were found when using different oils or when WPC concentration changes are produced.

\subsubsection{Effect of Oils}

At the beginning (day 0 ), the effect of oil used was not significant $(p>0.05)$. However for the following storage days: 7, 14, 21 and 70, PI had significantly lower values when corn oil was used $(p<0.05)$. Table 3 shows $p$-values from ANOVA.

These results can be explained by the difference in the concentration of antioxidant (vitamin E) and by the effect of heat treatment received. Although this vitamin is present in both oil sources, its concentration is higher in corn oil than in sunflower oil, $2.31 \mathrm{mg} / \mathrm{ml}$ and $0.54 \mathrm{mg} / \mathrm{ml}$ respectively. Vitamin $\mathrm{E}$ is temperature sensitive and losses could reach up to $55 \%$, decreasing its effective concentration in the product. Then we can consider that corn oil retains a higher residual activity of vitamin $\mathrm{E}$ than sunflower oil and that would be the cause of its greater stability during storage. [12].

Table 3. P-values for Oil and WPC from ANOVA of peroxide index

\begin{tabular}{cccccc}
\hline \multirow{2}{*}{ Factor } & \multicolumn{5}{c}{ Storage days } \\
\cline { 2 - 6 } & $\mathbf{0}$ & $\mathbf{7}$ & $\mathbf{1 4}$ & $\mathbf{2 1}$ & $\mathbf{7 0}$ \\
\hline Oil & 0.1284 & $<0.0001$ & $<0.0001$ & $<0.0001$ & $<0.0001$ \\
WPC & 0.1464 & 0.0027 & 0.0023 & 0.0238 & 0.0039 \\
\hline
\end{tabular}

\subsubsection{Effect of $W P C$}

$P$-values from ANOVA are presented in table 3.

As table 3 shows, significant differences were found at 7 , 14, 21 and 70 storage days, when WPC was used in different concentration levels.

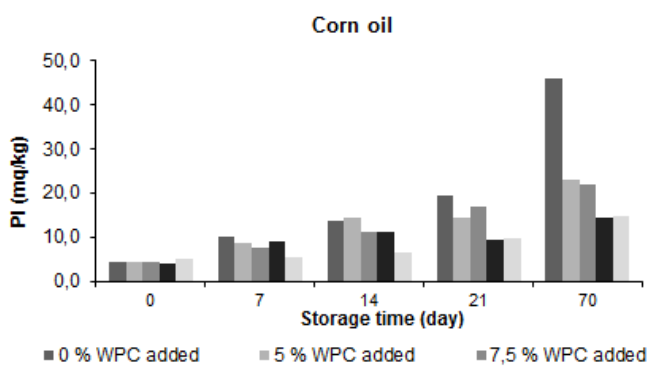
- $10 \%$ WPC added $\quad=15 \%$ WPC added

A

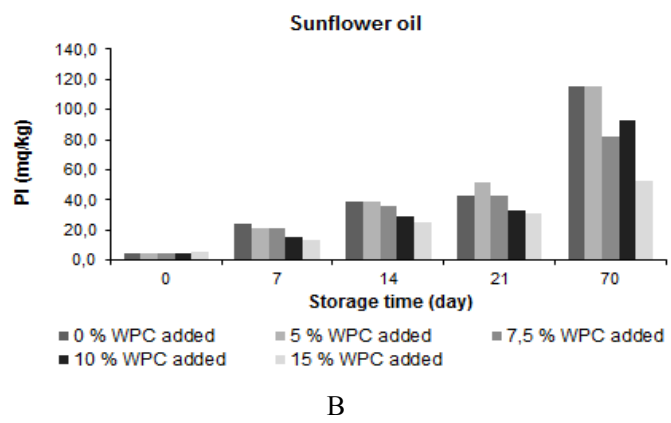

Figure 1. Peroxide Index of cookies at different storage time A: with corn oil and B: with sunflower oil 
Figure 1 shows a decrease in PI in cookies when WPC level increases from $0 \%$ to $15 \%$ considering any storage time. At the end of storage (day 70), with the highest concentration of WPC the peroxide production was diminished in a $54.4 \%$ with sunflower oil and a $68.2 \%$ with corn oil, compared to the control with $0 \%$ WPC. These results reflect the antioxidant effect of WPC added and are agree with other studies that have shown that after a hydrolysis, some resulting peptides can act as antioxidants in model systems and be used as natural antioxidants in food products [22]. Reference [23] showed that in cooked pork patties, WPC have a higher efficacy as antioxidant compared to soy protein isolate, vitamin E, BHA/BHT, rosemary, and ginseng. Only tea catechins showed a better oxidation inhibition than WPC. It has been mentioned that the antioxidant activity of peptides derived from whey is related to the presence of cysteine, which promotes glutathione synthesis, an intracellular potent antioxidant [24].

\subsection{Sensory Evaluation}

The averages of the sensory scores assigned by judges are presented in table 4 . Almost all cookies were evaluated as acceptable (score $\geq 6$ ) and rancidity was not perceived. Only two samples were assigned with score 5 and rancidity detectable, these samples correspond to cookies evaluated at day 70 , elaborated with sunflower oil and the lowest WPC dose (0 and $5 \%$ ). It is interesting to note that these samples presented the highest peroxides values (table 2).

Table 4. Flavour score and rancidity of cookies during storage

\begin{tabular}{|c|c|c|c|c|c|c|c|c|c|c|}
\hline \multirow{3}{*}{ WPC (\%) } & \multicolumn{5}{|c|}{ Corn oil } & \multicolumn{5}{|c|}{ Sunflower oil } \\
\hline & \multicolumn{5}{|c|}{ Storage (days) } & \multicolumn{5}{|c|}{ Storage (days) } \\
\hline & 0 & 7 & 14 & 21 & 70 & 0 & 7 & 14 & 21 & 70 \\
\hline 0 & $8(*)$ & $9(*)$ & $8.5(*)$ & $7(*)$ & $7(*)$ & $8(*)$ & $9(*)$ & $7(*)$ & $7(*)$ & $5(* *)$ \\
\hline 5 & $8(*)$ & $7.5(*)$ & $7(*)$ & $6(*)$ & $6(*)$ & $8(*)$ & $7(*)$ & $7(*)$ & $6(*)$ & $5(* *)$ \\
\hline 7,5 & $7\left(^{*}\right)$ & $8\left(^{*}\right)$ & $8(*)$ & $7\left(^{*}\right)$ & $6\left(^{*}\right)$ & $8(*)$ & $7.5\left(^{*}\right)$ & $7\left(^{*}\right)$ & $7.5\left(^{*}\right)$ & $6.5\left(^{*}\right)$ \\
\hline 10 & $8(*)$ & $7.5\left(^{*}\right)$ & $7(*)$ & $6(*)$ & $6(*)$ & $7(*)$ & $7(*)$ & $7(*)$ & $6\left(^{*}\right)$ & $5.5(*)$ \\
\hline 15 & $6(*)$ & $6(*)$ & $6(*)$ & $7(*)$ & $7(*)$ & $7(*)$ & $7.5\left(^{*}\right)$ & $7(*)$ & $7.5(*)$ & $7(*)$ \\
\hline
\end{tabular}

Rancidity: $(*)$ undetectable $(* *)$ detectable.

No significant differences were found in flavour when cookies were prepared with different oils $(\mathrm{p}>0.05)$, resulting indistinct for the panel to use sunflower or corn oil.

On the other hand and relative to the level of WPC replacement, differences were found only at storage days 0 and $7(p<0.05)$, This may be caused by the taste, described as "milky", of WPC proteins that partially mask other flavours that are generated during storage. From day 14, no significant differences in the flavour of the cookies at all levels WPC substitution were found. We see that the cookies with $0 \%, 5 \%, 7.5 \%$ and $10 \%$ replacement, who initially they had a higher score than the $15 \%$, reported a decrease in score during storage, while cookies with $15 \%$ WPC, which initially had the lowest value, could keep this value during the storage period. Finally, we believe that while the WPC gives a negative flavour, has a positive action such as the control over the peroxide index during storage.

\section{Conclusions}

In this study, cookies were prepared by replacing the traditionally used animal fat, by vegetable oils and with different WPC proportions with the aim of improving the nutritional quality and maintaining a high shelf life. According to the results of this research, an increase in shelf life was achieved in cookies elaborated with corn oil and with the highest WPC level.

\section{References}

[1] H. D. Sánchez, C. A. Osella, M. A.de la Torre, R. J. González y O. A. Sbodio. "Estudio nutricional relativo a proteínas, energía y calcio en niños que concurren a comedor escolar". Archivos Latinoamericanos de Nutrición, $1999,49(3): 218-222$.

[2] S. R. Pérez, C. A. Osella, M. A. de la Torre y H. D. Sánchez. "Efecto del mejoramiento proteico sobre los parámetros de calidad nutricional y sensorial de galletitas dulces (cookies). Archivos Latinoamericanos de Nutrición, 2008, 58(4):403410 .

[3] B. Munaza, S. G. M. Prasad and B. Gayas. "Whey proteins concentrate enriched biscuits". International Journal of Scientific and Research Publications, 2012, 2(8):1-4.

[4] H. Korhonen. "Milk-derived bioactive peptides: from science to applications". Journal of Functional Foods, 2009, 1: $177-187$.

[5] A. N. Visentín, S. R. Drago, C. A. Osella, M. A. de la Torre, H. D. Sánchez y R. J. González. "Efecto de la adición de harina de soja y concentrado proteico de suero de queso sobre la calidad del pan y la dializabilidad de minerales". Archivos Latinoamericanos de Nutrición, 2009, 59(39):325331.

[6] B. Bulut Solak and N. Akin. "Functionality of whey protein". International Journal of Health \& Nutrition, 2012, $3(1): 1-7$. 
[7] J. Jacob and K. Leelavathi. "Effect of fat-type on cookie dough and cookie quality". Journal of Food Engineering, 2007, 79(1):299-305.

[8] E. Muguerza, O. Gimeno, D. Ansorena and I. Astiasaran. "New formulations for healthier dry fermented sausages: a review". Trends in Food Science and Technology, 2004, 15:452-457.

[9] A. Valenzuela, J. Sanhueza, S. Nieto, G. Petersen y M. Tavella. "Estudio comparativo en fritura de la estabilidad de diferentes aceites vegetales". A\&G. Aceites y grasas, 2003, 13(4):568-573.

[10] E. A. Coppin and O. A. Pike. "Oil stability index correlated with sensory determination of oxidative stability in lightexposed soybean oil". Journal of the American Oil Chemists Society, 2001, 78(1):13-18.

[11] M. Baldioli, M. Servili, G. Perretti and G. F. Montedoro. "Antioxidant activity of tocopherols and phenolic compounds of virgin olive oil". Journal of the American Oil Chemists Society, 1996, 73(11):1589-1593.

[12] A. Kamal-Eldin. "Effect of fatty acids and tocopherols on the oxidative stability of vegetable oils". European Journal of Lipid Science and Technology, 2006, 108:1051-1061.

[13] G. O. Adegoke, M. Vijay Kumar, A. G. Gopala Krishna, M. C. Varadraj, K. Sambaiah, and B. R. Lokesh. "Antioxidants and lipid oxidation in foods- a critical appraisal". Journal of Food Science and Technology, 1998, 35:283-298.

[14] C. E.Stauffer. "Emulsifier: practical guides for the food industry". Eagan Press, St Poul, MN, USA, 1999.

[15] K. Warner and T. Nelsen. "AOCS collaborative study on sensory and volatile compound analyses of vegetable oils". Journal of the American Oil Chemists Society, 1996, $73: 157-165$.
[16] S. Armenta, S. Garrigues and M. de la Guardia. "Determination of edible oil parameters by near infrared spectrometry". Analytica Chimica Acta, 2007, 596(2):330 337.

[17] M. D. Mesa García, C. M. Aguilera García y A. Gil Hernández. "Efectos saludables de los lípidos de la dieta". Alimentación, Nutrición y Salud, 2007, 14(1):12-26.

[18] C. S. Gaines and C. C. Tsen. "A baking method to evaluate flour quality for rotary molded cookies". Cereal Chemistry, 1980, 57:429-433.

[19] AOAC. Association of Official Agricultural Chemists.Official methods of analysis. $15^{\text {th }}$ Edn. Washington, DC. 1990 .

[20] P. I. Zakrys, S. I. Hogan, M. G. O’Sullivan, P. Allenand and J. P. Kerry. "Effects of oxygen concentration on the sensory evaluation and quality indicators of beef muscle packed under modified atmosphere”. Meat Science, 2008, 19:648655 .

[21] Código Alimentario Argentino (CAA). Capítulo VII. Alimentos grasos aceites alimenticios. Art. 528 y 530.

[22] C. Alvarado Carrasco y M. Guerra. "Lactosuero como fuente de péptidos bioactivos". Anales Venezolanos de Nutrición, 2010, 23(1):45-50.

[23] T. L. McCarthy, J. P. Kerry, J. F. Kerry, P. B. Lynch and D. J. Buckley. "Evaluation of the antioxidant potential of naturalfood/plant extracts as compared with synthetic antioxidants and vitamin $\mathrm{E}$ in raw and cooked pork patties". Meat Science, 2001a, 57:45-52.

[24] K. Erdmann, B. Cheung and H. Schroder. "The possible roles of food-derived bioactive peptides in reducing the risk of cardiovascular disease". The Journal of Nutritional Biochemistry, 2008, 19:643-54. 